\title{
肺癌に合併する呼吸器感染症の意義
}

\section{Significance of respiratory infection in lung cancer}

今野 淳・本宮雅吉・大泉耕太郎・佐々木昌子・中井祐之・斎藤園子

渡辺 彰・富樫秀生・小犬丸貞裕・青沼清一・鈴木修治

\begin{abstract}
抄録：肺癌405例中肺感染を起こした152例について感染の意義を検討した。その結果，肺感染 は入院時既に $31 \%$ 存在し気管支の狭窄による閉塞性肺炎が多くみられた。原因菌とし てはグラム㓌性菌が多く検出された。肺感染合併例は非合併例に比べると感染前でッベ ルクリン反応が有意に減弱し，感染後は血清アルブミンが有意に減弱していた。感染の 誘因として白血球減少，ステロイド投与があったが白血球の減少は予後に重大な影響を

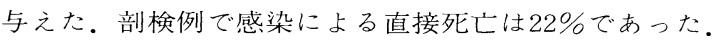

\section{はじめに}

肺癌は固型癌のうち最も治療困難な癌の一つ である。更に治療前，治療中に呼吸器の感染を 起こし易く, それが益々癌の治療を困難ならし める原因となっている。われわれは肺癌患者に 合併した呼吸器感染症について宿主側より, 又 菌側より種々検討を加えたので，その意義につ いて報告する。

\section{対象}

昭和 48 年 1 月から 52 年 12 月までの 5 年間に東 北大学抗酸菌病研究所, 及び仙台厚生病院に入 院した肺癌の患者は表 1 の如く, 405例で原発性 肺癌が357例, 転移性肺癌が48例であった。その 中, 類表皮癌は144例で40\%, 腺癌は125例で 35 $\%$, 小細胞癌が45例で13\%, 大細胞癌が37例で 10\%であった。その他, 組織型不明肺癌が 6 例 で2\%あった。

肺感染の定義として，1) $38^{\circ} \mathrm{C}$ 以上の発熱が 3 日以上続いたもの.2)白血球数が $8,000 / \mathrm{mm}^{3}$ 以 上. 3 ) 胸部X線上, 肺癌そのものとは別に炎症

東北大学抗酸菌病研究所内科
Table 1. Histological classification of lung cancer cases

\begin{tabular}{c|l|r}
\hline \multicolumn{2}{c|}{ Histology } & No. cases \\
\hline \multirow{4}{*}{ Primary } & Epidermoid car. & $144(40 \%)$ \\
1.c. & Adeno car. & $125(35 \%)$ \\
& Small cell car. & $45(13 \%)$ \\
& Large cell car. & $37(10 \%)$ \\
& Undetermined & $6(2 \%)$ \\
\hline Metastatic 1.c. & $357(100 \%)$ \\
\hline Total & Subtotal & 48 \\
\hline
\end{tabular}

性と思われる㓌影が認められたもので, 以上の 2 項目をもったものを肺感染症とした。肺癌患 者は抗癌剂の投与により白血球の減少するもの が多く，白血球の増多が必らずしも起こらない こと, 又胸部X 線上でも肺癌による無気肺の部 分に感染が起こるとX 線上必ずしも鑑別が容易 でないことなどから，上記の項目を肺感染とした。

1) 組織型

感染を起こした肺癌例は表 2 の如く, 原発性 肺癌が139例, 転移性肺癌が13例, 計152例で肺 癌症例全体の37\%が感染を起こした。原発性肺 
Table 2. Pulmonary infection in lung cancer

\begin{tabular}{lr}
\hline \multicolumn{1}{c}{ Histology } & No. cases \\
\hline Epidermoid car. & $64(46.0 \%)$ \\
Adeno car. & $43(30.9 \%)$ \\
Small cell car. & $15(10.8 \%)$ \\
Large cell car. & $13(9.4 \%)$ \\
Undetermined & $4(2.9 \%)$ \\
Subtotal & $139(100 \%)$ \\
\hline Metastatic 1.c. & 13 \\
\hline Total & 152 \\
\hline
\end{tabular}

癌の組織型は類表皮癌が 64 例で $46 \%$ ，腺癌が 43 例で30\%，小細胞癌が15例で10\%，大細胞癌 13 例で $9 \%$ で感染例では類表皮癌の症例が多い. これらの患者は内科で扱った患者で術後感染は 含まれていない。

\section{2) 肺癌の病期}

原発性肺癌の病期別分類でstage I, II の患者 は大体外科に廻して手術をするために少なく， それぞれ5例 (3.6\%), 22例(15.8\%)であり, stage III の inoperableの患者が圧倒的に多く 112 例 (80.6 $\%)$, 計139例 (100\%)である。全感染症例152例 に対して，入院時既に感染を起こしていた例が 47 例 $(31 \%)$ あった。

3) 年令

感染例の性，年令構成は表3の如く，男125例 $(82 \%)$ ，女 27 例 $(18 \%)$ である。男が多く，又年 令では60才台が最も多かった。

4) 感染の回数

入院期間中の感染発症の回数は 1 回のものが 原発性肺癌では118例と圧倒的に多く，2回のも のが17例あり，3 回が 3 例，4 回が 1 例と感染 を反復して起こすものも少数ながらあった。

\section{$5)$ 白血球数}

感染例の白血球数は表 4 の如く，大部分は 1 万から 2 万の間であるが， 2 万以上の例もかな りあり，また 8,000 以下の例も約 $1 / 5 に$ 存在した。 これらは抗癌剤の治療を行なって白血球が減少 しており，感染しても白血球が増さないものと 考えられた。

6) 癌病巣と感染病巣
Table 3. Sex and age distribution in the cases with pulmonary infection

\begin{tabular}{l|ccc}
\hline Age & Male & Female & Total \\
\hline $20 y-29 y$ & 1 & 0 & 1 \\
30y - 39y & 4 & 4 & 8 \\
40y - 49y & 9 & 4 & 13 \\
$50 y-59 y$ & 24 & 4 & 28 \\
$60 y-69 y$ & 54 & 9 & 63 \\
$70 y-$ & 33 & 6 & 39 \\
\hline & $125(82 \%) 27(18 \%)$ & $152(100 \%)$ \\
\hline
\end{tabular}

Table 4. White blood cell counts in the cases with pulmonary infection

\begin{tabular}{c|c|c|c}
\hline & Primary & Metastatic & Total \\
1.c. & 1.c. & \\
\hline$>20,000$ & 20 & 2 & $22(12.4 \%)$ \\
$10,000-20,000$ & 95 & 9 & $104(58.8 \%)$ \\
$8,000-10,000$ & 16 & 1 & $17(9.6 \%)$ \\
$<8,000$ & 31 & 3 & $34(19.2 \%)$ \\
\hline & 162 & 15 & $177(100 \%)$ \\
\hline
\end{tabular}

原発性肺癌における癌病巣と感染病巣の関係 をみた。132例中, 同側同部位の例が119例で, 癌病巣と感染病巣が異なる例は20例で, 同側同 部位が多数を占めた。癌の発生部位をみると左 右の主気管支に発生した癌が右 42 例, 左 24 例あ り，左右の肺葉気管支に発生したものが右42例 で上葉20例，中葉 4 例，下葉18例であった。左 は14例で上葉10例，下葉 4 例であった。末梢の 肺癌に合併した感染例は右が10例，左が 1 例の みであった。

\section{7 ）喀痰中分離菌}

図 1 は感染症の起こる前の喀痰中分離菌であ るが，感染前ではグラム院性菌が65\%で，その 中Klebsiella pneumoniaeが最も多く, 次がH.influenzae, Pseudomonasであった。グラム陽性 菌は34\%で，最も多いのがStreptococcus pneumoniaeで, Staphylococcusは少数であった。困 2 は治療後の菌の分布であるが, グラム㓌性菌 が増えて74\%になり, しかもKleasiellaが増えて 
Fig. 1. Microorganisms isolated from sputum in the beginning of pulmonary infection (139 strains)

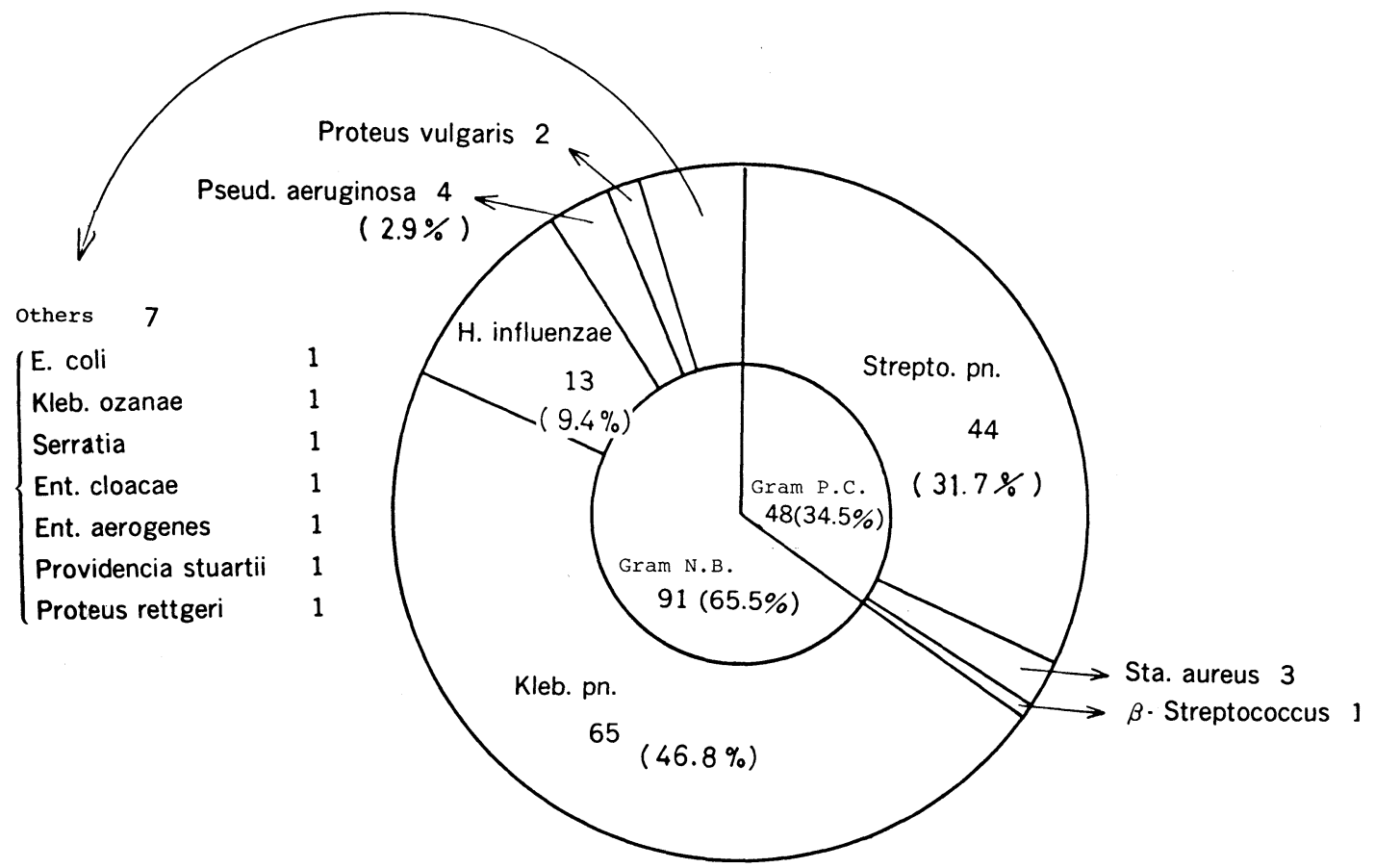

Fig. 2. Microorganisms isolated from sputum after the treatment of pulmonary infection (104 strains)

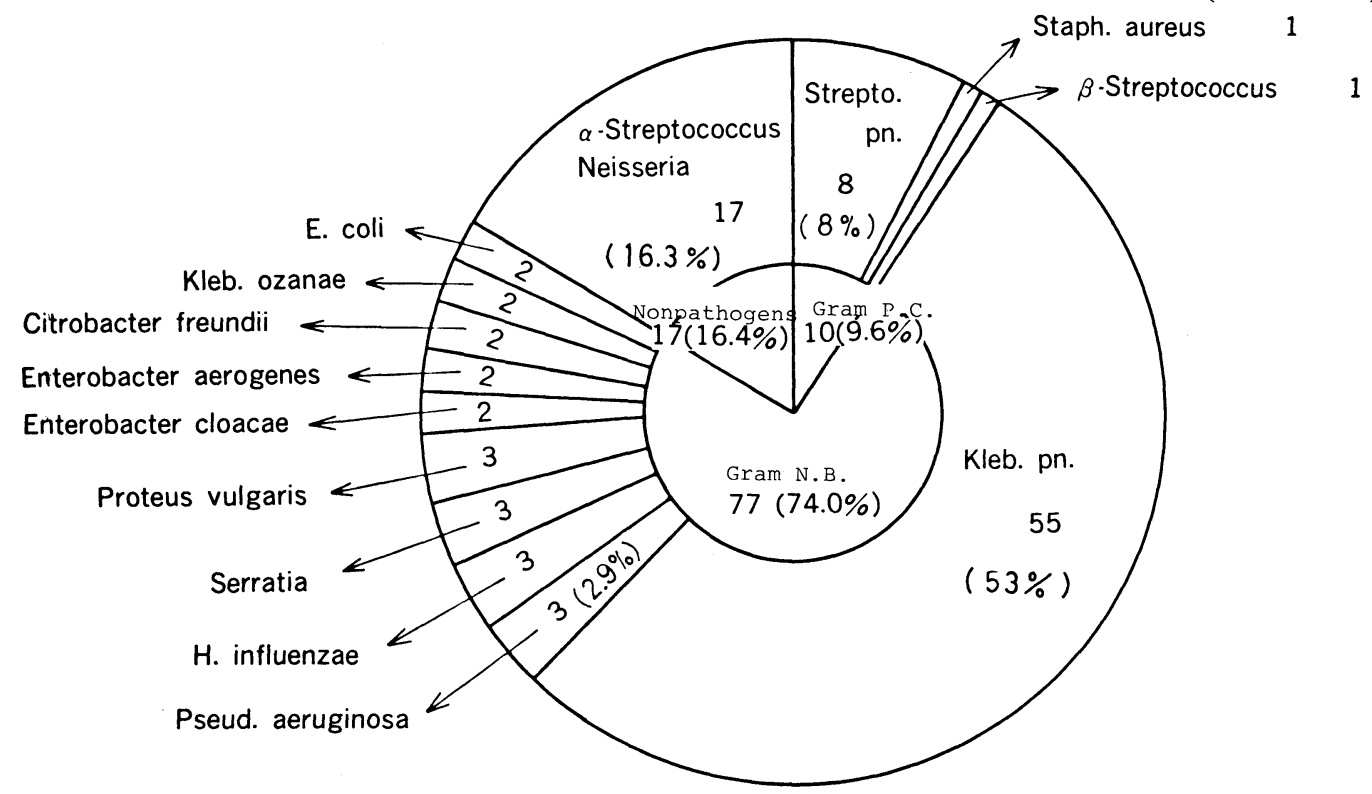

いる.グラム陽性菌は $9 \%$ と減少して， $\alpha$-streptococcus Neisseriaのような非病原菌が增之て いる. 真菌ではcandidaが治療前より治療後に多 くなり，治療前にはなかったAspergillusが見ら
れた。また剖検でPneumocystis cariniiが 1 例発 見された。

8）肺癌における体液性免疫：血清総蛋白量, 血清アルブミン值, $r$ グロブリン值 
一般状態の良否を知る目的で血清総蛋白量を 感染群と非感染群とに分け，感染群では感染前 と感染後の血清総蛋白量を测定した。非感染群 では入院時と入院後経過中を比較した。感染群 では感染前総蛋白量平圴 $6.92 \pm 0.55 \mathrm{~g} / \mathrm{dl}$ で, 感 染後は6. $54 \pm 0.79 \mathrm{~g} / \mathrm{dl}$ と $10 \%$ 危険率で有意に 減少した。非感染群では入院時 $6.78 \pm 0.71 \mathrm{~g} / \mathrm{dl}$ より入院後の $6.45 \pm 0.68 \mathrm{~g} / \mathrm{dl}$ と $1 \%$ 危険率で 有意に減少した。しかし, 感染群と非感染群の 間には有意の差は認めなかった。

血清アルブミン值も同様に, 感染, 非感染共 に入院後に入院時の值に比べ有意に低下してい た。即ち, 感染群では感染前の血清アルブミン 值は3.632 $00.608 \mathrm{~g} / \mathrm{dl}$ で感染後は3.175 00.631 $\mathrm{g} / \mathrm{dl}$ と $1 \%$ 危険率で有意に減少している。ま た非感染群では入院時 $3.739 \pm 0.574 \mathrm{~g} / \mathrm{dl}$ よ入 院後 $3.420 \pm 0.633 \mathrm{~g} / \mathrm{dl}$ と $1 \%$ 危険率で有意に 減少している，血清アルブミンの場合は感染群 と非感染群とでは経過後の值は感染群の方が 1 \%の危険率で有意に非感染群より減少していた。

体液性免疫状態を比較するため, 血清 $\boldsymbol{\gamma}$ ーグロ ブリン值の動態を観察した。感染群の血清 ロブリンは感染前 $1.430 \pm 0.81 \mathrm{~g} / \mathrm{dl}$ で, 感染後は $1.541 \pm 0.729$ で推計学的には差はなかった。ま た非感染群では入院時 $1.240 \pm 0.398 \mathrm{~g} / \mathrm{dl} て ゙$, 入

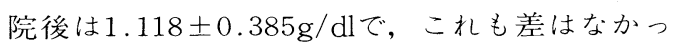
たが, 感染群と非感染群の経過後の值は $1 \%$ の 危険率で感染群の感染後の方が非感染群の入院 後の方に比べて高值を示した。

9）肺癌における細胞性免疫：ツベルクリン反 応, リン八球数

細胞性免疫状態を比較する目的で, 感染群, 非感染群で入院時のツベルクリン反応の大きさ を比較した。発赤の長径を比較すると, 感染群 (stage III)では $15.22 \mathrm{~mm} \pm 9.83$, 非感染群( sta-

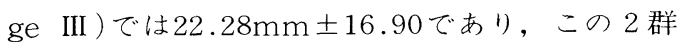
の值の間には危険率 $1 \%$ 以下で有意差を認めた。 即ち, 感染群で遅延型反応の低下を認めた。

さらに感染群の中で感染持続のまま死亡した 群と, 感染が一旦㳂癒したのちに死亡した群と でリンパ球数の動態を観察した。感染が一旦治 瘾した群では感染発症時と感染治療時とを比較
Table 5. Predisposing factor of infection

\begin{tabular}{llr}
\hline & Predisposing factor & Cases \\
\hline & Bronchography & 9 \\
\hline & Bronchoscopy & 6 \\
\hline & Leucopenia & 10 \\
\hline & Steroid administration & 9 \\
\hline \multirow{4}{*}{$\begin{array}{l}\text { Cold caught during temporary } \\
\text { out-of -hospital stay }\end{array}$} & 4 \\
\hline \multirow{4}{*}{$\begin{array}{l}\text { Aspiration of blood related } \\
\text { to hemoptysis }\end{array}$} & 3 \\
\hline \multirow{4}{*}{$\begin{array}{l}\text { Under- } \\
\text { lying }\end{array}$} & Congestive heart failure & 2 \\
\cline { 2 - 3 } disease & Honey comblung & 2 \\
\cline { 2 - 3 } & $\begin{array}{l}\text { Pulmonary fibrosis }+ \\
\text { bronchiectasis }\end{array}$ & 1 \\
\cline { 2 - 3 } & Bronchopleural fistula & 1 \\
\cline { 2 - 3 } & Diabetes mellituts & 2 \\
\hline & Total & 49 \\
\hline
\end{tabular}

した場合，感染前は1,651 $\pm 961 \mathrm{cell} / \mathrm{ml} ゙$, 感染 後は $1,580 \pm 1,010 \mathrm{cell} / \mathrm{ml}$ でリンハ球数は推試学 的に增減なしであった。これに対し, 感染死し た群では, 感染発症時のリンバ球数は1697.98 $1128.05 \mathrm{cell} / \mathrm{ml}$ であるのに対し，感染後は 1183 $\pm 936 \mathrm{cell} / \mathrm{ml}$ であり, 感染死亡群の方が感染後 は感染前に比べ有意差を以ってリンパ球が減少 していた。

\section{0）感染の誘因：}

感染は気管の狭窄圧迫という物理的な理由に よって起こるものが多いが, その他の誘因とし て表 5 の如きものがあげられる。ブロンコグラ フィー, ブロンコスコピー後の感染は軽症の例 が多い。白血球減少，ステロイド投与の感染の 加わった例は重症が多かった。また基礎疾患を もった患者が感染を起こすと重症が多く死亡゙例 もあった。な拀，われわれは，ステロイドを投 与する際はINHを併用しているので, ステロイ ドによる結核の発病は認められなかった。

11) 肺感染症の転帚：

肺癌感染症152例について転帰を調べた。感染 症が加わったものを治癒例, 不変例, 増悪例と 分けると，表 6 の如く，治癒したものの中には 肺癌そのものが良くなり軽快退院したものが 28 例あり, 癌が悪くなって退院したものが13例, 
Table 6. Prognosis of cases with pulmonary infection

\begin{tabular}{l|l|c}
\hline Course of infection & Course of 1.c. & No. of cases \\
\hline Healed & $\begin{array}{l}\text { Improved and } \\
\text { discharged } \\
\text { Worse and } \\
\text { discharged } \\
\text { Died }\end{array}$ & 28 \\
\hline No change & $\begin{array}{l}\text { Worse and } \\
\text { discharged }\end{array}$ & 3(1) \\
\hline Worse & Died & 52(9) \\
\hline \multicolumn{2}{|c}{ Total 152(13) } \\
\hline \multicolumn{2}{|c}{ ( ) metastatic 1.c. }
\end{tabular}

死亡したものが56例あった。感染症が不変のも ので悪化退院したものが3例あった。增㯖して 死亡したものが52例で，全体の152例中, 34\%が 感染により全身状態が悪化して死亡している。 いかに肺癌において感染が重要かつ死亡と関連 しているかがわかる。

12）肺癌二次感染例の生存期間：

感染して治癒したが死亡した56例と感染が治 らないで死亡した52例の生存期間をみると，図 3 の如く感染非治瘾群は治療群に比べて著るし く生存期間が短かく, 50\%が 3 週以内で死亡し, 全例が 6 ヶ月以内に死亡した。それに比へ感染 治瘾群は生存期間がはるかに長く，50\%死亡は 3 力月であった。抗癌剤，あるいは放射線治療

Fig. 3. Life span after pulmonary infection

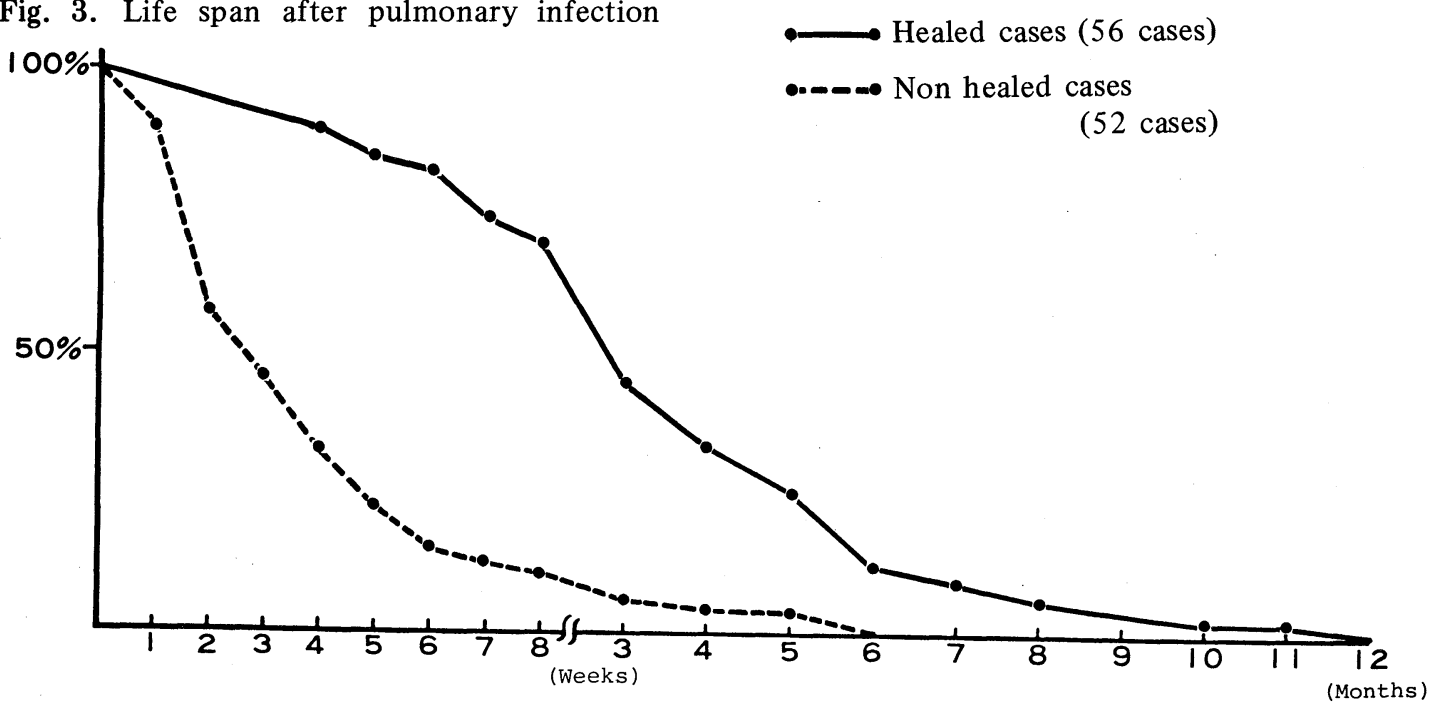

で白血球が3,000以下になった例で感染を合併し た例と感染のない例を比較した。図 4 の如く, 8例づつあったがNadir後の生存期間をみると感 染合併例に明らかな生存期間の短維がみられた。

13）肺癌剖検例の感染症 :

剖検例でみると原発性肺噳59例, 転移性肺癌 8 例で, 計67例あった。その組織型の比率は表 7 の如く, 入院した肺癌患者総数における細胞 診による比率と略, 同じであった。肺感染を合 併した例は原発性肺癌28例, 転移性肺癌 2 例で 計30例あった。表 8 は肺感染を合併したものの 内訳で, 肺炎が25例, 肺膿瘍が 2 例, びまん性 間質性肺炎 1 例であるが, 感染が死亡の直接死 因と認められるものは15例で，剖検例中30例， $44 \%$ が肺感染を認め, その中, 15例 $22 \%$ が直接 死因と考之られた。

14）肺癌の汸療と感染：

肺癌に感染症が加わった場合に抗癌剤の治療 がどこまで実施されたのかをみた。抗癌剤の投 与や放射線療法を繰返し施行できたものをIntensive treatment 例 (I.T) とし, 評価可能の最少限 の治療ができた例をMinimum Effective dose例 (M.E.D)，殆ど抗癌剤の治療を行なわれなかっ た例をLess Minimum Effective dose例 (Less M.E.D）と3段階に分けた。表 9 の如く, Intensi ve treatmentができた例は29例あり，その中， 抗癌剂㳂療前に肺感染合併例は 4 例, $14 \%$ しか 
Fig. 4. Life span after Nadir (WBC less than 3,000) with and without pulmonary infection

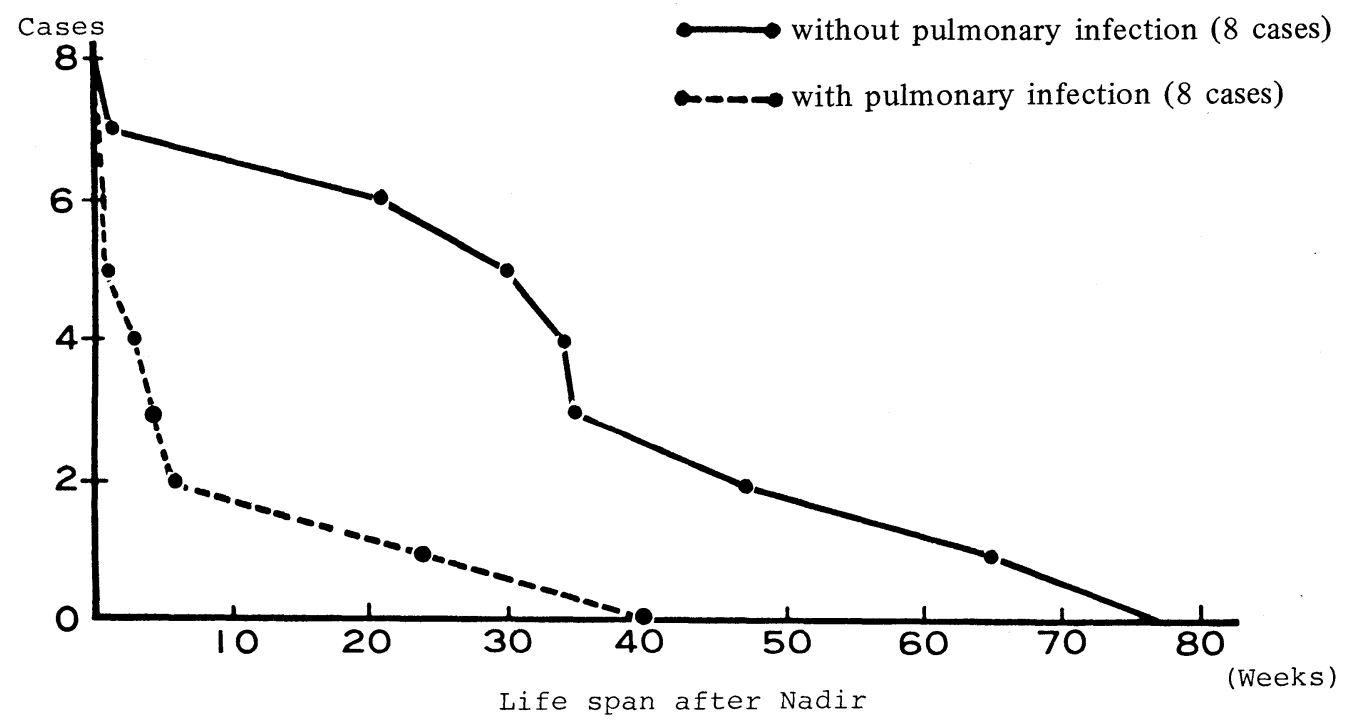

Table 7. Histological classification of autopsied cases with pulmonary infection

\begin{tabular}{l|c|c}
\hline \multicolumn{1}{c|}{ Histology } & $\begin{array}{c}\text { No. of } \\
\text { autopsied cases }\end{array}$ & $\begin{array}{c}\text { Pulmonary } \\
\text { infection }\end{array}$ \\
\hline Epidermoid car. & $23(39.0 \%)$ & $9(32.1 \%)$ \\
Adeno car. & $21(35.6 \%)$ & $11(39.3 \%)$ \\
Large cell car. & $7(11.9 \%)$ & $4(14.3 \%)$ \\
Small cell car. & $8(13.5 \%)$ & $4(14.3 \%)$ \\
Subtotal & $59(100 \%)$ & $28(100 \%)$ \\
Metastatic 1.c. & 8 & 2 \\
\hline Total & 67 & 30 \\
\hline
\end{tabular}

なく，癌治療中に感染が起きたものは11例，38 $\%$ で 1 例が抗癌剂を中止しており, 癌治療後に 14例，48\%が感染を合併している. M.E.D症例 は70例で癌治療開始前に30例, 43\%が感染を合 併し, 癌治療中には19例，27\%が感染を合併し， 抗癌剂を中止したものが 9 例もあった。治療後 には21例，30\%が合併していた。

Less M.E.D症例は18例中癌治療前が12例, 67 \%あり, 癌治療中は 4 例, 22\%で全例が癌治療 を中止している．癌治療後に起こした例が 2 例, 11\%であった。これを見ると, 癌治療前に感染 を起こしたものは抗癌剂の治療が充分できず,
Table 8. Pulmonary infection as direct cause of death in the autopsied cases

\begin{tabular}{|c|c|c|c|}
\hline Lung cancer & \multicolumn{2}{|c|}{ Pulmonary infection } & \multirow{2}{*}{\begin{tabular}{|c|}
$\begin{array}{c}\text { Direct cause } \\
\text { of death }\end{array}$ \\
11 \\
\end{tabular}} \\
\hline \multirow{3}{*}{$\begin{array}{c}\text { Primary } \\
\text { 1.c. }\end{array}$} & Pneumonia & 25 & \\
\hline & Lung abscess & 2 & 1 \\
\hline & $\begin{array}{l}\text { Diffuse } \\
\text { interstitial } \\
\text { pneumonia }\end{array}$ & 1 & 1 \\
\hline $\begin{array}{c}\text { Metastatic } \\
\text { 1.c. }\end{array}$ & Pneumonia & 2 & 2 \\
\hline \multicolumn{3}{|c|}{ Autopsied cases $30(44.8 \%)$} & $15(22.4 \%)$ \\
\hline \multicolumn{3}{|c|}{$67(100 \%)$} & \\
\hline
\end{tabular}

また治療をしたとしても途中で止める例が多く， 感染は抗癌剂の治療に関しても重大な影響を与 えていることがわかる。

\section{考按}

肺は外界と直接交通する器官であり, 最も感 染を受け易い器官である。併し, 通常は外界か ら気道に入った細菌は線毛運動により下気道か ら上気道に押し上げられ，声带より下は無菌の 状態である。肺癌の場合，気管支に腫瘍が突出 することが多く，気管支は一部または大部分が 
Table 9. Effect of pulmonary infection on cancer treatment

\begin{tabular}{l|c|c|c}
\hline \multicolumn{1}{c|}{ Grade of } & \multicolumn{2}{|c}{ Time of pulmonary infection } \\
\cline { 2 - 4 } cancer treatment & $\begin{array}{l}\text { Before } \\
\text { cancer treatment }\end{array}$ & $\begin{array}{l}\text { During } \\
\text { cancer treatment }\end{array}$ & $\begin{array}{l}\text { After } \\
\text { cancer treatment }\end{array}$ \\
\hline $\begin{array}{l}\text { Intensive } \\
\text { treatment } \quad 29 \text { cases }\end{array}$ & $4(14 \%)$ & $\begin{array}{l}11(38 \%) \\
\text { (discontinuation } \\
\text { of } \\
\text { treatment 1 case) }\end{array}$ & $14(48 \%)$ \\
\hline $\begin{array}{l}\text { Minimum } \\
\text { effective } \\
\text { dose }\end{array}$ & $30(43 \%)$ & $\begin{array}{l}19(27 \%) \\
\text { (discontinuation } \\
\text { of cases } \\
\text { treatment } 9 \text { cases) }\end{array}$ & $21(30 \%)$ \\
\hline $\begin{array}{l}\text { Less } \\
\text { minimum } \\
\text { effective dose }\end{array}$ & $12(67 \%)$ & $\begin{array}{l}4(22 \%) \\
\text { (discontinuation } \\
\text { of } \\
\text { treatment 4 cases) }\end{array}$ & $2(11 \%)$ \\
\hline
\end{tabular}

閉塞される。したがって腫瘍より末梢部分は喀 痰が停滞し, 細菌の発育に絶好の培地となる。 これは閉塞性肺炎と呼ばれ, 肺炎の影に肺癌が ひそんでいることが常に鑑別診断上，重要な問 題となる.'

われわれの肺癌症例では152症例中 $37 \%$ が感染 を起こしている。志摩らは121例について肺感 染をしらべ38\%と報告している.2)組織別では類 表皮癌が最も多く $46 \%$ であった。熊谷らは $60 \%$ の高率に認められたと報告している。肺癌の治 療を行なった場合，殊に抗癌剤の使用により白 血球の減少し，感染を起こしても白血球の増多 がみられないものが約 $1 / 5$ 存在した。喀痰中分離 菌はグラム㓌性菌が65\%で過半数を占めていた。 原ら ${ }^{4)}$, 5 に上ると肺癌に合併する感染症の起炎 菌は昭和 40 年代前半ではグラム陽性菌が多かっ たが, 後半ではグラム陰性菌が多く検出される ようになったという. Price ${ }^{6)}$ らも近年肺炎の中 にグラム除性菌による肺炎が多くなったと報告 している。われわれの例もグラム㓌性菌が多く, Klebsiella pneumoniaeが最も多くみられ, 次が H. influenzaeでグラム陽性菌では, Strept. pneumoniaeが最も多くみられた。治療後は抗生物質 に敏感に反応するグラム陽性菌が減少し, Klebsiella pneumoniaeを主体とするグラム㓌性菌が 大幅に増加した。またPseudomonas, Serratia， Enterobacter, Citrobacterなど菌交代現象と思 われる菌毛出現している。
肺癌患者の体液性免疫機能を血清総蛋白量, 血清アルブミン值，r-グロブリン值をみたが入 院後いづれも低下するが, 血清アルブミン值は 感染群と非感染群とでは感染群の方が有意に低 下した。また血清子ーグロブリン值は感染群の方 が有意に高値を示した。那須 ${ }^{7)}$ はr゙グロブリン 值は肺炎合併との間に有意な関連性を認めなか ったという，細胞性免疫を比較するため、ツべ ルクリン反応，末梢血のリンパ球数をみた。ツ ベルクリン反応では感染群が有意に低值を示し， またリンパ球数は感染が原因で死亡した例では 有意差をもって感染群が低值を示した。那須 ${ }^{7}$ も感染群では有意にリンパ球数が低下すると述 べている。感染が起これば血清アルブミン值は 減少し, ツベルクリン反応, リンパ球数も減少 する。体液性細胞性免疫が両方侵され，肺癌で むしばまれた体力が更に低下することになる。 できるだけ感染をさけなければならない。感染 の誘因として重症なものは白血球減少，ステロ イド投与などがあげられた。抗癌剤の投与によ り白血球の減少は避けられないが，一定数以下 にならないように注意する必要がある。またス テロイドも大量長期連用により重篤な肺感染症 を起こして死亡することがあるので注意を要す る。感染を起こした肺癌152例中, 感染が増悪し，

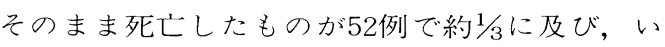
かに肺癌に感染が加わると治療が困難であるか ということがわかる。その生存期間は感染非治 
瘾群は $50 \%$ が 3 週以内に死亡し, 全例が 6 カ月 以内に死亡している. 殊に白血球が 3,000 以下で 感染を起こしたものは生存期間が短縮している. したがって, 肺癌の治療中, 放射線療法, 化学 療法に際しては, 白血球が3,000以下にならない ようにしなければならない。 剖検例では67例中，感染が死亡の直接原因々 考えられたものは15例で22\%であった。橋本ら は肺癌剖検例 41 例の中, 感染が直接死因々考之

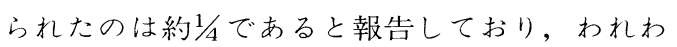
れの例と略一致する。

今度は視点を変えて抗癌剂の投与および放射 線治療など癌の治療と他感染との関連をみると, 癌の治療が繰返しできたIntensive treatment例 と最少限にできたMinimum effective dose例, 殆ど治療できなかったLess minimum effective dose例に分けると, 癌の治療がintensiveに施行で きた例は治療前, 治療中に感染が加わらなかっ た例が多く、肺感染のあるものには癌の治療が 殆んどできなかった症例が多かったことを示し ている。感染は抗癌郕の投与に関して, 重大な 影響を与えているといえる。堀内ら ${ }^{9)}$ は急性白 血病95例について抗腫癔剂投与後の肺炎併発を 観察したが，末期より緩解導入期に多く白血球 が少なく, 胸部X線像は間質性肺炎像を呈し重篤 であり，肺水腫様の所見を呈するとのべている. 肺癌に対して強力な抗癌剂を使用している時も このような例に遭遇するので注意を要する。

内海 ${ }^{10)}$ は抗癌剤を投与された患者の剖検所見 で結核症が相当みられ，しかも類上皮細胞，ラ
ングハンス巨細胞，乾酪巣など全く変化がみら れず，ただ壊死巣の中に結核菌のみが純培養と も言えるほど多数增殖している像が見られたと 記載しているが，われわれの例ではステロイド を投与する時は常にINHを併用しているので結 核の発症はみられなかった。

\section{まとめ}

1 ）肺感染合併例は肺癌405例中152例，37\%で あった。

2 ）肺感染は入院時既に 47 例 $31 \%$ に存在した。

3) 肺感染は大きな気管支の狭窄による閉塞性 肺炎が多かった。

4) 喀痰よりの検出菌はグラム陰性菌, 特にク レブシェラH. influenzaeが多かった。グラ 么陽性菌では肺炎球菌が多かった。

5 ) 肺感染合併例, 非合併例を比べると, 感染 前では合併例でッベルクリン反応が減弱し, 感染後では血清アルブミンが減少した。

6 ）感染の誘因として白血球減少，ステロイド 投与があった. 白血球 3,000 以下では予後に 重大な影響があった。

7 ) 剖検例中感染による直接死亡は $22 \%$ あっ た。

8 ）感染が加わると肺癌に対する治療が充分に できない例が多い。

9 ) 予防ではステロイドの大量長期投与をさけ, 抗癌剤に上る白血球の減少に注意する必要 がある。

\section{交 献}

1) 山本二三子, 他：肺癌, 16, 202, 1974 .

2) 志摩 清, 他：肺癌, 16, 173, 1976.

3）熊谷謙二, 他：肺癌, 14, 200, 1974 .

4）原 耕平, 他：肺癌, 14, 200, 1974 .

5）原 耕平, 他：肺癌, Suppl. p.43, 1977.

6) Price, A, K. and Sanford, J. P.: ARRD, 110, 647, 1974 .
7) 那須 勝 : Chemotherapy, 24, 552, 1976.

8）橋本武志, 他：肺癌，14，202，1974.

9）堀内 篤, 他：日胸疾会誌, 12 , 增刊号, p. 50, 1974.

10）内海邦輔：日本化療学会抄録集，p.58， 1978. 


\title{
Significance of respiratory infection in lung cancer
}

\author{
Kiyoshi KONNO, Masakichi MOTOMIYA, Kotaro OIZUMI, \\ Masako SAKAKI, Yushi NAKAI, \\ Sonoko SATTO, Akira WATANABE, \\ Hideo TOGASHI, Sadahiro KOINUMARU, \\ Seiichi AONUMA and Shuji SUZUKI
}

Department of Internal Medicine

The Research Institute for Tuberculosis and

Cancer, Tohoku University, Sendai

The secordary infection of the lung in association with lung cancer was found in 152 of 405 cases $(37 \%)$. The secondary infection was found in 47 of 152 cases at the time of admission. In most cases the secondary infection resulted from narrowing of the large bronchi. Gram-negative bacteria, especially klebsiella pneumoniae were found frequently in sputum. There was a tendency for those who showed weakly positive tuberculin reaction to be susceptible to secondary infections. The level of serum albumin in these cases tended to become lower after infection. Leucopenia and treatment with steroid hormons were the major predisposing factors of the secondary infections. The prognosis was very poor in those cases with leucopenia of below 3,000. The pulmonary infection was the direct cause of death in $22 \%$ of the cases, the diagnosis of which were verified at autopsy. The response to treatment with anti-cancer drugs was unsatisfactory secondary infections occurred. In order to prevent the occurrence of secondary infections, it is recommended to avoid the administration for extended preiods of a large dosis of steroid hormons and to exercise due caution to the number of leucocytes. 